\title{
PLASMA PROGESTERONE AND OESTROGENS IN SHEEP DURING LATE PREGNANCY: CONTRIBUTION OF THE MATERNAL ADRENAL AND OVARY
}

\author{
F. N. THOMPSON* AND W. G. WAGNER \\ Veterinary Medical Research Institute, Iowa State University, \\ Ames, Iowa 50010, U.S.A.
}

(Received 28th September 1973)

\begin{abstract}
Summary. Levels of progesterone were determined by competitive protein-binding techniques and oestrogens by radio-ligand binding techniques in the uterine and peripheral plasma of parturient ewes. Uterine progesterone levels began a continuous decline 4 to 5 days ante partum whereas jugular levels only declined 1 or 2 days ante partum. Peripheral plasma progesterone levels were significantly elevated in ewes carrying multiple fetuses compared to those in ewes with a single fetus. A similar but non-significant difference existed in the uterine plasma. Adrenalectomized and adrenalectomized-ovariectomized ewes had lower progesterone levels in the peripheral blood but not lower uterine levels than did control ewes. Ovariectomy did not affect progesterone levels. Oestrone and oestradiol values were lower in the uterine venous concentrations of adrenalectomized and adrenalectomizedovariectomized ewes. A depression of oestrogen values before birth was not noted in ovariectomized ewes. It is concluded that the maternal adrenal has a definite rôle in oestrogen biosynthesis in pregnant sheep.
\end{abstract}

\section{INTRODUCTION}

Although progesterone concentrations during pregnancy in sheep have been reported (Bassett, Oxborrow, Smith \& Thorburn, 1969; Fylling, 1970; Thorburn \& Mattner, 1971; Moore, Barrett \& Brown, 1972; Stabenfeldt, Drost \& Franti, 1972), the contribution of the maternal adrenal gland to the plasma progesterone concentration is not well described. The adrenal secretion of progesterone was small as calculated from concentrations in the adrenal venous effluent of two pregnant ewes (Linzell \& Heap, 1968). Urinary excretion of pregnanetriol and pregnanediol was reduced in an adrenalectomized pregnant woman (Charles \& co-authors, 1970). Progesterone synthesis proceeded from pregnenolone in sheep placental preparations (Ainsworth \& Ryan, 1967), but the adrenal contribution of precursors for placental progesterone production has not been reported.

* Present address: Department of Physiology-Pharmacology, University of Georgia, Athens, Georgia 30601, U.S.A. 
According to the concept of the feto-placental unit, placental oestrogen synthesis in women results from placental hydrolysis and aromatization of androgen sulphates originating from the fetus (Diczfalusy, 1969). Dehydroepiandrosterone sulphate originating from the maternal adrenal gland also contributed significantly to placental oestradiol and oestrone production (Siiteri \& MacDonald, 1966). Further evidence to support the rôle of the maternal adrenal in oestrogen biosynthesis is found in the report that administration of dehydroepiandrosterone sulphate dramatically increased oestrone and oestradiol production in a pregnant adrenalectomized woman (Gurpide \& Vande Wiele, 1971). In sheep, oestrogen biosynthesis in vitro only proceeded when either maternal or fetal adrenal tissue was incubated simultaneously with placental tissue (Davies, Ryan \& Petro, 1970), but the relative importance of the maternal adrenal to oestrogen biosynthesis in sheep is not known.

Maintenance of gestation in sheep is independent of the ovary after the first third (Denamur \& Martinet, 1955). Late in gestation, the ovarian contribution to the maternal plasma progesterone levels has been reported to be small in sheep (Moore et al., 1972). By contrast, Fylling (1970) did not observe in ovariectomized ewes the normal increase in plasma progesterone found in late pregnancy. In order to investigate the steroidogenic rôle of the maternal adrenal in ewes during late pregnancy, this study involved ovariectomized ewes as well as adrenalectomized ewes. The contribution of the ovary to the steroid milieu of the sheep during late pregnancy is also reported.

\section{MATERIALS AND METHODS}

Western crossbred ewes with known breeding dates were randomly assigned to one of four treatment groups. Seven ewes were in the intact control group, six in the adrenalectomy group (AD) and four ewes each in the ovariectomy $(\mathrm{OV})$ and adrenalectomy-ovariectomy (AD-OV) groups. Surgical procedures for adrenalectomy, ovariectomy and cannulation have been previously described (Thompson \& Wagner, 1974). Following surgery, blood samples were collected daily from the jugular and uterine veins. The blood was chilled, and the plasma was harvested and stored at $-20^{\circ} \mathrm{C}$ until assay.

Plasma progesterone was determined by the competitive protein-binding method (Neill, Johansson, Datta \& Knobil, 1967) as modified by Wagner, Strohbehn \& Harris (1972). Briefly, this method involves the addition of a tracer amount of $\left[4-{ }^{14} \mathrm{C}\right]$ progesterone for recovery purposes followed by petroleum ether extraction. The extract was purified on thin-layer chromatograms (N-HR/UV 254, Machery-Nagel). After elution, progesterone was quantified by its ability to displace $\left[1,2-{ }^{3} \mathrm{H}\right]$ corticosterone from a solution containing adrenalectomized dog plasma as the binder. The coefficient of variation calculated for duplicate plasma samples for the entire range averaged $21 \%$.

Oestrone and oestradiol were extracted from the plasma with anhydrous diethyl ether and separated on celite columns. The eluates were assayed by radio-ligand techniques using rabbit uterine cytosol as the binding protein (Korenman, 1970). The coefficient of variation calculated for duplicate plasma samples for the entire range was $13 \%$. 


\section{Data analysis}

Day 0 was the day of parturition. Day- 0 samples were defined as the last which were collected before parturition and Day +1 was the first day on which samples were collected after parturition. Mean differences were tested for statistical significance by Student's $t$ test and correlation coefficients were calculated for the oestrogen values (Snedecor \& Cochran, 1967).

\section{RESULTS}

Uterine plasma progesterone levels were significantly $(P<0.05)$ higher than jugular levels in all treatment groups. This relationship for the control group is illustrated in Text-fig. 1. Progesterone levels began a consistent decline in the

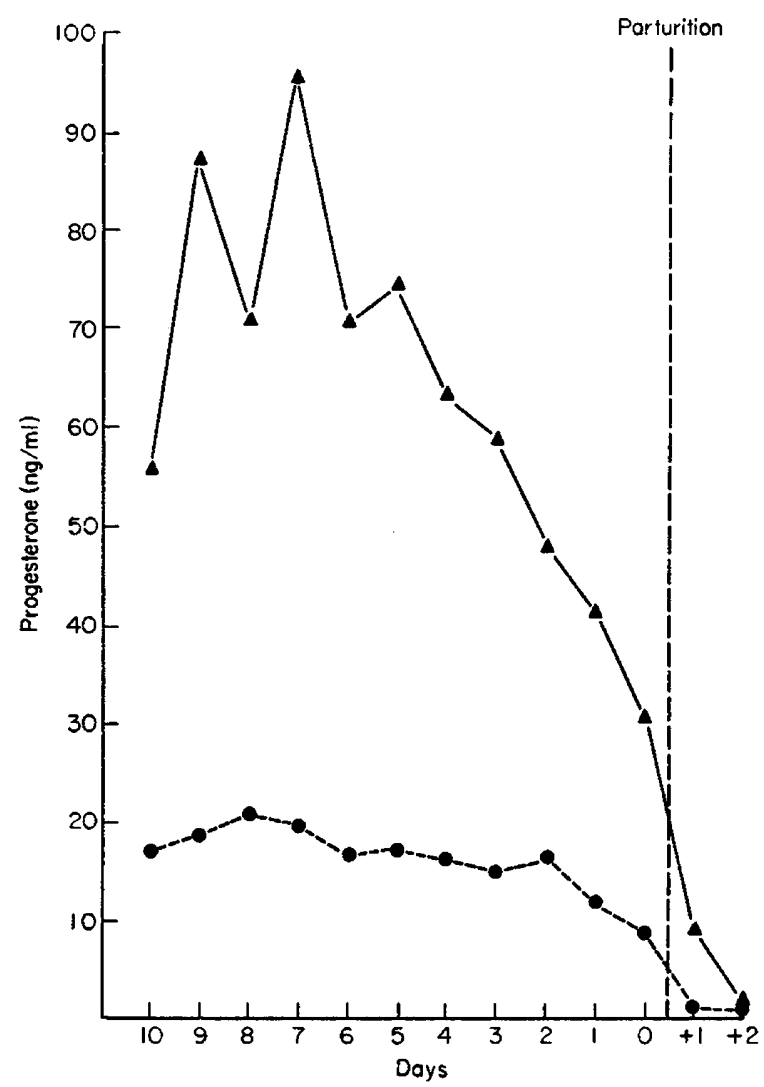

Text-Fig. 1. Progesterone levels in the uterine $(\Delta)$ and jugular $(\bullet)$ venous plasma of control sheep before and after parturition.

uterine plasma on Day -4 whereas jugular levels only declined consistently on Days -1 and 0 . By Day +2 , progesterone levels had declined in all treatment groups in the jugular plasma to $1.0 \mathrm{ng} / \mathrm{ml}$ and to $1.9 \mathrm{ng} / \mathrm{ml}$ or less in the uterine plasma.

Plasma progesterone levels were higher in both sites in ewes carrying 
multiple fetuses than in those with a single fetus (Text-fig. 2). This difference was significant $(P<0.05)$ in the peripheral plasma for the entire period before birth, but only on certain days in the uterine plasma. The ratio of ewes carrying multiple to single fetuses was $4 / 3,3 / 3,1 / 3$ and $2 / 2$ in the control, $A D, O V$ and $\mathrm{AD}-\mathrm{OV}$ groups, respectively. Since the presence of multiple lambs in utero affected progesterone levels, the difference in this ratio was normalized to

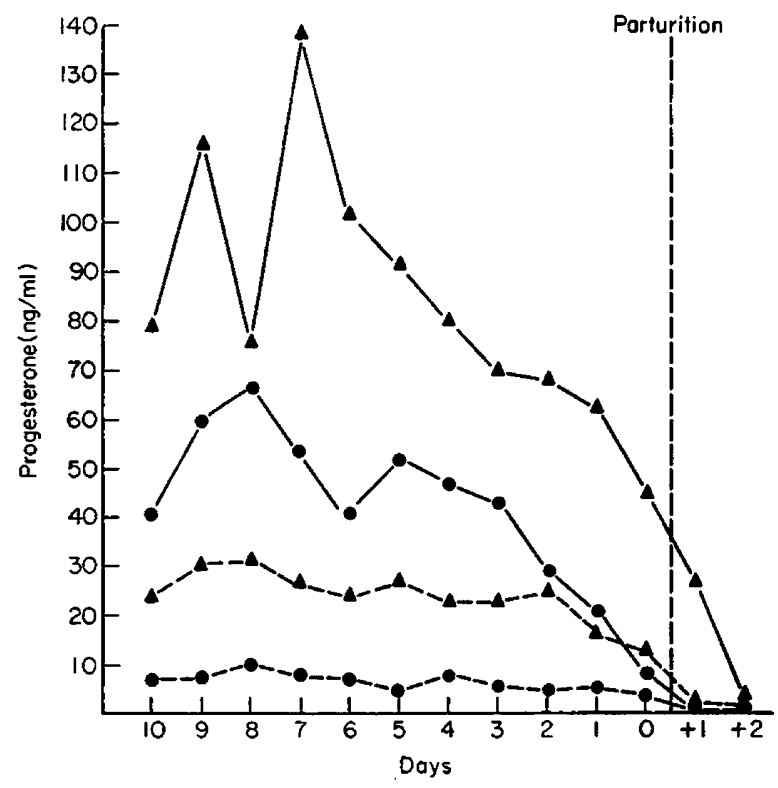

Text-Fig. 2. Progesterone levels before and after parturition in the uterine $(-)$ and jugular (- - ) venous plasma of sheep carrying single $(\bullet)$ or multiple $(\mathbf{\Lambda})$ fetuses.

Table 1. Peripheral plasma progesterone levels in control, adrenalectomized and adrenalectomized-ovariectomized pregnant ewes

\begin{tabular}{l|cccc}
\hline & \multicolumn{5}{|c}{ Days before parturition } \\
& 9 & 7 & 5 & 3 \\
\hline Control & $18 \cdot 9 \pm 6 \cdot 4(6)$ & $18 \cdot 6 \pm 4 \cdot 7(5)$ & $16 \cdot 5 \pm 5 \cdot 6(6)$ & $13 \cdot 4 \pm 4 \cdot 4(6)$ \\
AD & $10 \cdot 4 \pm 2 \cdot 3(5)$ & $7 \cdot 1 \pm 1 \cdot 1(6) *$ & $10 \cdot 0 \pm 2 \cdot 7(6)$ & $9 \cdot 8 \pm 2 \cdot 6(6)$ \\
AD-OV & $13 \cdot 6 \pm 7 \cdot 7(3)$ & $13 \cdot 1 \pm 4 \cdot 6(4)$ & $10 \cdot 8 \pm 2 \cdot 9(4)$ & $9 \cdot 2 \pm 3 \cdot 6(4)$ \\
\hline
\end{tabular}

Values are expressed as mean \pm S.E. in $\mathrm{ng}$ progesterone/ml. Figures in parentheses are the number of observations. $A D$, adrenalectomized ewes; AD-OV, adrenalectomized-ovariectomized ewes.

$$
* P<0 \cdot 05 \text {. }
$$

permit a consideration of differences between experimental groups. After deleting a control ewe with triplets, an equal ratio of ewes with twin fetuses to those with single fetuses was present in the control, AD and AD-OV groups. Peripheral plasma progesterone was consistently reduced in AD and AD-OV ewes (Table 1). This difference was only significant, however, on Day -7 in the AD ewes. The OV ewes could not be normalized in this manner but three 
OV ewes with single lambs had a mean jugular progesterone value for the period from Day -9 to Day -1 of $8.1 \mathrm{ng} / \mathrm{ml}$ compared to $6.7 \mathrm{ng} / \mathrm{ml}$ for three control ewes with single lambs during this period. Uterine plasma progesterone levels for these ewes during this interval were $49.8 \mathrm{ng} / \mathrm{ml}$ and $44.7 \mathrm{ng} / \mathrm{ml}$ for OV and control ewes, respectively.

Uterine oestrone levels in control ewes before birth were slightly greater than corresponding jugular levels (Text-fig. 3). Uterine oestrone concentrations

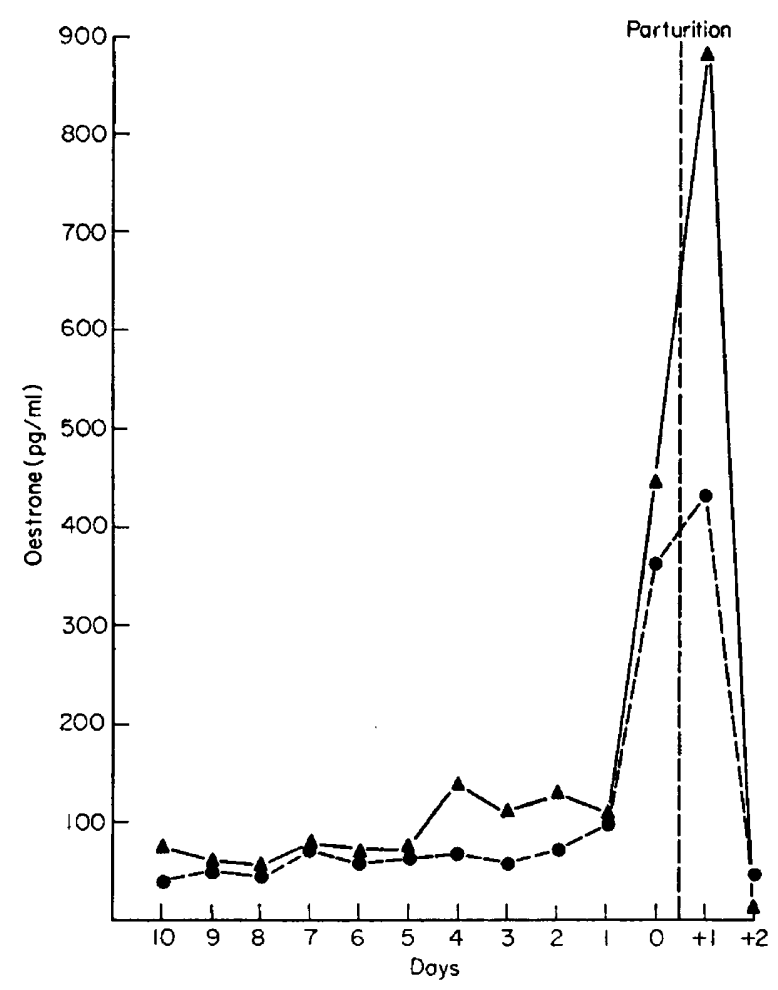

TEXT-FIG. 3. Oestrone levels in the uterine (A) and jugular (๑) venous plasma of control sheep before and after parturition.

increased from a mean of $74.8 \mathrm{pg} / \mathrm{ml}$ on Day -5 to levels greater than $100 \mathrm{pg} / \mathrm{ml}$ on Day -4 (Table 2). On the day of parturition, oestrone levels increased dramatically in both sites. An intact ewe sampled within $1 \mathrm{hr}$ after parturition had the highest oestrone values; these were $2970 \mathrm{pg} / \mathrm{ml}$ and $2329 \mathrm{pg} / \mathrm{ml}$ in the uterine and jugular veins, respectively. If these values were not included in the calculation of mean oestrone values on Day +1 , the means for that day would be $179.8 \mathrm{pg} / \mathrm{ml}$ and $116.5 \mathrm{pg} / \mathrm{ml}$ for the uterine and jugular veins, respectively. Only in two intact ewes was there a marked elevation (greater than $400 \mathrm{pg} / \mathrm{ml}$ ) in uterine oestrone values on both Days 0 and +1 . Therefore, peak oestrone levels generally had a duration of $24 \mathrm{hr}$ or less. By Day +2 , oestrone concentrations had fallen sharply in both sampling locations. Oestrone 
values in ewes with multiple fetal lambs were not different from those in ewes with a single fetal lamb.

Although there was daily fluctuation in mean oestrone levels before birth, AD and AD-OV ewes invariably had lower levels than control ewes (Table 2). Mean oestrone uterine levels calculated for the period from Days -9 to

Table 2. Oestrone levels in the uterine plasma of control, adrenalectomized and adrenalectomized-ovariectomized ewes before and after parturition

\begin{tabular}{|c|c|c|c|c|}
\hline Days* & Control & $A D$ & $O V$ & $A D-O V$ \\
\hline $\begin{array}{r}-9 \\
-8 \\
-7 \\
-6 \\
-5 \\
-4 \\
-3 \\
-2 \\
-1 \\
0 \\
+1 \\
+2\end{array}$ & $\begin{array}{c}59 \cdot 4 \pm 9 \cdot 7(6) \\
52 \cdot 3 \pm 7 \cdot 7(6) \\
77 \cdot 2 \pm 27 \cdot 8(6) \\
68 \cdot 5 \pm 10 \cdot 5(5) \\
74 \cdot 8 \pm 23 \cdot 2(7) \\
137 \cdot 1 \pm 56 \cdot 6(6) \\
110 \cdot 2 \pm 29 \cdot 6(5) \\
127 \cdot 0 \pm 28 \cdot 6(6) \\
108 \cdot 8 \pm 22 \cdot 1(7) \\
443.5 \pm 169 \cdot 0(5) \\
877.4 \pm 703 \cdot 2(4) \\
11.3 \pm 11 \cdot 3(2)\end{array}$ & $\begin{array}{l}30 \cdot 1 \pm 8 \cdot 9(4) \\
37 \cdot 1 \pm 5 \cdot 7(6) \\
53 \cdot 3 \pm 17 \cdot 5(6) \\
58 \cdot 4 \pm 17 \cdot 3(6) \\
34 \cdot 2 \pm 6 \cdot 5(6) \\
41 \cdot 1 \pm 8 \cdot 0(6) \\
51 \cdot 9 \pm 14 \cdot 5(6) \\
39 \cdot 5 \pm 8 \cdot 9(6) \\
77.3 \pm 25 \cdot 2(5) \\
180 \cdot 0 \pm 36 \cdot 8(5) \\
111 \cdot 8 \pm 55 \cdot 2(4) \\
24 \cdot 4 \pm 10 \cdot 7(4)\end{array}$ & $\begin{array}{c}74 \cdot 5 \pm 17 \cdot 7(3) \\
66 \cdot 4 \pm 14 \cdot 6(3) \\
70 \cdot 9 \pm 18 \cdot 7(3) \\
137 \cdot 6 \pm 81 \cdot 6(3) \\
52 \cdot 3 \pm 13 \cdot 1(3) \\
58 \cdot 7 \pm 7 \cdot 6(4) \\
58 \cdot 5 \pm 7 \cdot 2(4) \\
74 \cdot 7 \pm 15 \cdot 2(4) \\
119 \cdot 6 \pm 50 \cdot 8(4) \\
255 \cdot 3 \pm 80 \cdot 1(4) \\
45 \cdot 0 \pm 6 \cdot 0(2) \\
25 \cdot 4 \pm 4 \cdot 6(3)\end{array}$ & $\begin{array}{l}51 \cdot 5 \pm 13 \cdot 3(3) \\
48 \cdot 0 \pm 6 \cdot 1(3) \\
55 \cdot 5 \pm 8 \cdot 6(4) \\
57 \cdot 8 \pm 15 \cdot 6(4) \\
54 \cdot 4 \pm 7 \cdot 3(4) \\
52 \cdot 5 \pm 12 \cdot 1(4) \\
56 \cdot 3 \pm 12 \cdot 9(4) \\
60 \cdot 5 \pm 20 \cdot 8(3) \\
48 \cdot 0 \pm 9 \cdot 0(3) \\
69 \cdot 8 \pm 8 \cdot 3(2) \\
29 \cdot 4 \pm 12 \cdot 6(2) \\
24 \cdot 0 \pm 7 \cdot 5(2)\end{array}$ \\
\hline
\end{tabular}

Values are expressed as mean \pm S.E. in pg oestrone $/ \mathrm{ml}$. Figures in parentheses are the number of observations. AD, adrenalectomized ewes; $O V$, ovariectomized ewes; AD-OV, adrenalectomized-ovariectomized ewes.

* Days before $(-)$ and after $(+)$ parturition.

Table 3. Oestradiol levels in the uterine plasma of control, adrenalectomized and adrenalectomized-ovariectomized ewes before and after parturition

\begin{tabular}{c|c|c|c|c}
\hline Days* & Control & \multicolumn{1}{|c|}{$A D$} & \multicolumn{1}{|c|}{$O V$} & $A D-O V$ \\
\hline-9 & $16 \cdot 7 \pm 3 \cdot 2(6)$ & $33 \cdot 8 \pm 10 \cdot 6(4)$ & $26 \cdot 6 \pm 4 \cdot 3(3)$ & $19 \cdot 9 \pm 9 \cdot 6(3)$ \\
-8 & $29 \cdot 8 \pm 15 \cdot 9(6)$ & $17 \cdot 1 \pm 2 \cdot 6(6)$ & $42 \cdot 3 \pm 17 \cdot 3(3)$ & $19 \cdot 7 \pm 7 \cdot 7(3)$ \\
-7 & $34 \cdot 4 \pm 17 \cdot 7(6)$ & $11 \cdot 0 \pm 4 \cdot 1(6)$ & $21.9 \pm 3 \cdot 8(3)$ & $16 \cdot 1 \pm 5 \cdot 9(4)$ \\
-6 & $18 \cdot 1 \pm 5 \cdot 1(5)$ & $15 \cdot 5 \pm 3 \cdot 7(6)$ & $35 \cdot 1 \pm 15 \cdot 4(3)$ & $16 \cdot 5 \pm 6 \cdot 0(4)$ \\
-5 & $20 \cdot 6 \pm 4 \cdot 5(7)$ & $17 \cdot 7 \pm 1 \cdot 7(6)$ & $19.9 \pm 6 \cdot 2(3)$ & $19 \cdot 2 \pm 6 \cdot 4(4)$ \\
-4 & $20 \cdot 3 \pm 5 \cdot 6(6)$ & $17 \cdot 1 \pm 2 \cdot 4(6)$ & $34 \cdot 5 \pm 11 \cdot 6(4)$ & $16 \cdot 5 \pm 5 \cdot 6(4)$ \\
-3 & $21 \cdot 4 \pm 10 \cdot 7(4)$ & $16 \cdot 3 \pm 2 \cdot 6(5)$ & $33 \cdot 3 \pm 8 \cdot 1(4)$ & $21 \cdot 2 \pm 5 \cdot 0(4)$ \\
-2 & $35 \cdot 7 \pm 14 \cdot 5(6)$ & $14 \cdot 7 \pm 4 \cdot 0(6)$ & $42 \cdot 1 \pm 14 \cdot 3(4)$ & $26 \cdot 0 \pm 4 \cdot 8(3)$ \\
-1 & $28 \cdot 3 \pm 6 \cdot 0(7)$ & $24 \cdot 7 \pm 8 \cdot 4(5)$ & $33 \cdot 8 \pm 8 \cdot 1(4)$ & $20 \cdot 1 \pm 8 \cdot 9(3)$ \\
0 & $56 \cdot 7 \pm 13 \cdot 7(5)$ & $64 \cdot 1 \pm 16 \cdot 2(5)$ & $75 \cdot 6 \pm 21 \cdot 3(4)$ & $90 \cdot 0 \pm 78 \cdot 0(2)$ \\
+1 & $93 \cdot 3 \pm 60 \cdot 2(4)$ & $26 \cdot 6 \pm 16 \cdot 3(4)$ & $18 \cdot 0 \pm 18 \cdot 0(2)$ & $3 \cdot 0 \pm 3 \cdot 0(2)$ \\
+2 & $6 \cdot 8 \pm 6 \cdot 2(2)$ & $8 \cdot 3 \pm 2 \cdot 1(4)$ & $14 \cdot 3 \pm 3 \cdot 9(3)$ & $18 \cdot 8 \pm 12 \cdot 8(2)$ \\
\hline
\end{tabular}

Values are expressed as mean \pm S.E. in pg oestradiol $/ \mathrm{ml}$. Figures in parentheses are the number of observations. $\mathrm{AD}$, adrenalectomized ewes; OV, ovariectomized ewes; AD-OV, adrenalectomized-ovariectomized ewes.

* Days before $(-)$ and after $(+)$ parturition.

Day -1 were $90 \cdot 0 \pm 12 \cdot 4,47 \cdot 3 \pm 10 \cdot 0,79 \cdot 1 \pm 19 \cdot 5$ and $54 \cdot 3 \pm 7 \cdot 5 \mathrm{pg} / \mathrm{ml}$ (mean \pm S.E.) for the control, $A D, O V$ and $A D-O V$ ewes, respectively. These levels in control ewes were significantly $(P<0.05)$ greater than those in either $\mathrm{AD}$ or $\mathrm{AD}-\mathrm{OV}$ ewes. Oestrone levels increased markedly at parturition in all groups and were quite low by Day +2 . 
Oestrone concentrations before birth were found to be greater than oestradiol concentrations. The difference between the daily oestradiol levels in the jugular and uterine plasma was small and there was often a slightly greater concentration in the jugular plasma. Daily oestradiol concentrations before birth were frequently reduced in the $\mathrm{AD}$ and $\mathrm{AD}-\mathrm{OV}$ ewes (Table 3 ). For the period from Days -9 to Day -1 , mean uterine oestradiol levels were $25 \cdot 1 \pm 6 \cdot 4,19 \cdot 2 \pm 2 \cdot 1$, $34.0 \pm 7.9$ and $17.0 \pm 3.0 \mathrm{pg} / \mathrm{ml}$ in the control, $\mathrm{AD}, \mathrm{OV}$ and $\mathrm{AD}-\mathrm{OV}$ ewes, respectively. On Day 0, oestradiol levels increased sharply in all treatment groups. Significant positive correlations were demonstrated between oestrogen concentrations in the two sampling sites $(r=0.973$ for uterine and jugular oestrone; $r=0.703$ for uterine and jugular oestradiol) and between uterine oestrone and oestradiol concentrations $(r=0 \cdot 816)$.

Gestation lengths were not reduced by adrenalectomy ( $145 \cdot 8$ days in control and 146.2 days in $\mathrm{AD}$ ewes) but ovariectomized ewes had a shorter mean gestation length (143.7 days in OV and 141.8 days in AD-OV ewes). All the adrenalectomized ewes gave birth to live lambs, but several $\mathrm{AD}$ ewes not included in the data lost their lambs several days after abdominal surgery for ovariectomy and/or cannulation procedures.

\section{DISGUSSION}

Progesterone concentrations in the uterine venous plasma generally agree in magnitude and with the observed decline before birth reported by other workers for the ewe (Thorburn \& Mattner, 1971; Bedford, Challis, Harrison \& Heap, 1972; Moore et al., 1972). This decline does not seem to be the result of haemodilution since uterine blood flow decreases towards the end of gestation in the ewe (Huckabee, Crenshaw, Curet \& Barron, 1972). Only on the day of parturition has an increased uterine blood flow been reported (Bedford, Challis, Harrison \& Heap, 1972). This decline implies that preparation for lambing began at least several days before parturition.

A ready explanation for the progesterone decline was not found in a study of progesterone metabolism in ewes during late pregnancy since the metabolic clearance rate of progesterone rose only slightly while the conversion of progesterone to $20 \alpha$-dihydroprogesterone was lowest at this stage of gestation (Bedford, Harrison \& Heap, 1972). In rats during the last half of gestation, the enzymatic activity of $20 \alpha$-hydroxysteroid dehydrogenase and $5 \alpha$-steroid dehydrogenase increased greatly in uterine tissue (Flint \& Armstrong, 1973). In rat uterine tissue, both the concentration (Davies \& Ryan, 1973) and activity (Davies \& Ryan, 1972) of progesterone receptors were markedly decreased near term. Therefore, at least in the rat and perhaps in sheep, uterine progesteronebinding is decreased and uterine progesterone metabolism is accelerated in preparation for parturition.

A similar decline was not manifested in the peripheral plasma progesterone values. These results are similar to those reported by Bassett et al. (1969) who found a relatively high progesterone concentration present in the ewe until the time of lambing. Fylling (1970) reported that the peripheral plasma progresterone values reached a maximum late in gestation and then declined. Results 
from this study are in general agreement since the highest levels found were on approximately Days 138 and 139 of gestation (Days -7 and -8 ). In contrast to the late decline found in this study, Stabenfeldt et al. (1972) reported a consistent decline in peripheral plasma progesterone values in ewes approximately 1 week before parturition.

A significant elevation of peripheral plasma progesterone concentrations in ewes with twin fetal lambs compared to those with a single fetal lamb has also been reported by Bassett et al. (1969). It can be concluded from the uterine levels that this difference is attributable to increased placental progesterone production. The production rate of progesterone has been related to the lamb's birth weight as it was found to be significantly greater in ewes bearing fetuses with birth weights greater than $4 \mathrm{~kg}$ than in ewes with smaller lambs (Bedford, Harrison \& Heap, 1972). Progesterone production may also be related to placental mass.

After considering progesterone values only from $\mathrm{OV}$ and control ewes with single fetuses, ovariectomy did not reduce progesterone levels in the ewe during late pregnancy. This confirms an earlier report that the ovarian contribution to the circulating progesterone levels was small in the ewe before birth (Moore et al., 1972).

Conversely, removal of the maternal adrenal glands resulted in a reduction of peripheral but not uterine plasma progesterone values. A markedly lowered plasma corticoid concentration was present in these ewes (Thompson \& Wagner, 1974) which may have affected progesterone metabolism. This explanation becomes more tenable when it is considered that the adrenal gland was found to contribute only a very small amount of progesterone directly to the circulation of the pregnant ewe (Linzell \& Heap, 1968). Since uterine progesterone levels were not reduced in adrenalectomized ewes in this study, this confirms the earlier report that the adrenal gland was not supplying significant amounts of precursors for placental progesterone synthesis. Data from other investigators (Dickson \& Seekins, 1963; Harrison, Heap \& Paterson, 1972) and from this study suggest that the adrenalectomized ewe is especially prone to pregnancy loss. These losses may be related to the decreased peripheral plasma progesterone reported here, but the adrenalectomized ewes also displayed some inappetence and their gluconeogenic ability probably was reduced.

A further indication of preparation for lambing was the increase in the mean uterine oestrone levels that occurred several days ante partum. The abrupt increase in the circulating oestrogens only on the day of parturition further substantiates reports by others (Challis, 1971; Obst \& Seamark, 1972;Thorburn, Nicol, Bassett, Shutt \& Cox, 1972). The finding that oestrone was quantitatively the greatest circulating oestrogen in the parturient ewes also agrees with these reports. A physiological significance is not concluded from the difference in the peak oestrone levels on Day 0 , since samples were collected once daily and the duration of peak values was short.

The decreased uterine oestrogen production in $\mathrm{AD}$ and $\mathrm{AD}-\mathrm{OV}$ ewes indicates that the maternal adrenal gland was supplying a significant amount of oestrogen precursors for placental synthesis. In this respect, therefore, sheep 
are similar to women (Siiteri \& MacDonald, 1966). Since the uterine oestrone levels were reduced by 40 to $43 \%$ and oestradiol levels by 24 to $32 \%$ in the AD and $\mathrm{AD}-\mathrm{OV}$ groups, the conceptus made the major contribution to the circulating oestrogen levels. Apparently a similar situation exists in women as urinary excretion of oestrone and oestradiol was $1 / 4$ of the normal pregnancy level in those with anencephalic fetuses (Frandsen \& Stakemann, 1964).

In the ewe during late pregnancy, the ovary clearly was not involved in oestrogen biosynthesis. On the basis of the shortened gestation lengths in the $\mathrm{OV}$ and $\mathrm{AD}-\mathrm{OV}$ ewes, an effect of the ovary on pregnancy could be postulated. This observation, however, is at variance with the results of Denamur \& Martinet (1955) and Fylling (1970) who did not find an alteration of gestation length in the ovariectomized ewe.

\section{ACKNOWLEDGMENTS}

We wish to thank Mr Ronald E. Strohbehn and Miss Patsy Anne Harris for their technical assistance and Mr Roy Van Zee for care of the animals. The data were taken from a thesis submitted by F.N.T. to the Graduate College, Iowa State University, in partial fulfilment of the requirements for a Ph.D. degree.

This study was supported in part by funds from General Research Support Grant No. 5-SOI-RR-05565-07, National Institutes of Health.

\section{REFERENCES}

Ainsworth, L. \& Ryan, K. J. (1967) Steroid hormone transformations by endocrine organs from pregnant animals. II. Formation and metabolism. Endocrinology, 81, 1349.

Bassett, J. M., Oxborrow, T. J., Smith, I. D. \& Thorburn, G. D. (1969) The concentration of progesterone in the peripheral plasma of the pregnant ewe. F. Endocr. 45, 449.

Bedpord, C. A., Chaliss, J. R. G., Harrison, F. A. \& Heap, R. B. (1972) The rôle of oestrogens and progesterone in the onset of parturition in various species. 7. Reprod. Fert., Suppl. 16, 1.

Bedford, G. A., Harrison, F. A. \& HEAP, R. B. (1972) The metabolic clearance rate and production rate of progesterone and the conversion of progesterone to 20x-hydroxypregn-4-en-3-one in the sheep. F. Endocr. 55, 105.

Challis, J. R. G. (1971) Sharp increase in free circulating oestrogens immediately before parturition in sheep. Nature, Lond. 229, 208.

Charles, D., Harkness, R. A., Kenny, F. M., Menini, E., Ismail, A. A., Durkin, J. W. \& Loraine, J. A. (1970) Steroid excretion patterns in an adrenalectomized woman during three successive pregnancies. Am. 7. Obstet. Gynec. 106, 66.

Davies, I. J. \& RyAn, K. J. (1972) The uptake of progesterone by the uterus of the pregnant rat in vivo and its relationship to cytoplasmic progesterone-binding protein. Endocrinology, 90, 507.

Davies, I. J. \& RYAN, K. J. (1973) The modulation of progesterone concentration in the myometrium of the pregnant rat by changes in cytoplasmic "receptor" protein activity. Endocrinology, 92, 394.

Davies, I. J., Ryan, K. J. \& Petro, Z. (1970) Estrogen synthesis by adrenal-placental tissues of the sheep and the iris monkey in vitro. Endocrinology, 86, 1457.

Denamur, R. \& Martinet, J. (1955) Effets de l'ovariectomie chez la brebis pendant la gestation. C. r. Séanc. Soc. Biol. 149, 2105.

Dickson, W. M. \& SeEkins, J. (1963) Blood plasma 17-hydroxycorticosteroid, blood glucose, and blood ketone concentrations in intact and adrenalectomized pregnant ewes subjected to reduced food intake. Am. F. vet. Res. 25, 955.

Diczfalusy, E. (1969) Steroid metabolism in the fetoplacental unit. In The Feto-Placental Unit, p. 65. Eds. A. Pecile and C. Finzi. Excerpta Medica, Amsterdam.

Flint, A. P. F. \& ARmstrong, D. T. (1973) The appearance of an endometrial $20 \alpha$-hydroxysteroid dehydrogenase toward the end of pregnancy in the rat. Endocrinology, 92, 624.

Frandsen, V. A. \& Stakemann, G. (1964) The site of production of oestrogenic hormone sin human pregnancy with anencephalic foetus. Acta endocr., Copenh. 47, 265. 
Fylling, P. (1970) The effect of pregnancy, ovariectomy and parturition on plasma progesterone levels in sheep. Acta endocr., Copenh. 65, 273.

GURPIDE, E. \& VANDE WiELE, R. L. (1971) Utilization of ingested dehydroisoandrosterone sulfate for the production of estrogens by normal and adrenalectomized pregnant subjects. F. Steroid Biochem. 2, 11.

Harrison, F. A., Heap, R. B. \& Paterson, J. Y. F. (1972) Pregnancy in adrenalectomized ewes: glucose production and steroid changes in late gestation. F. Physiol., Lond. 227, 21 P.

Huckabee, W. E., Grenshaw, M. G., Curet, L. B. \& Barron, D. H. (1972) Uterine blood flow and oxygen consumption in the unrestrained pregnant ewe. Q.F. exp. Physiol. 57, 12.

Korenman, S. G. (1970) Radio-ligand binding procedures for estrogen assay in normal and pregnancy plasma. In Steroid Assay by Protein Binding, p. 291. Ed. E. Diczfalusy. Bogtrykkeriet Forum, Copenhagen.

LiNZeit, J. L. \& HeAP, R. B. (1968) A comparison of progesterone metabolism in the pregnant sheep and goat: sources of production and an estimation of uptake by some target organs. $\mathcal{F}$. Endocr. 41, 433.

Moore, N. W., Barrett, S. \& Brown, J. B. (1972) Progesterone concentrations in maternal and foetal blood plasma of ewes. J. Endocr. 53, 187.

Neill, J. G., Johansson, E. D. B., Datta, J. K. \& Knobir, E. (1967) Relationship between the plasma levels of luteinizing hormone and progesterone during the normal menstrual cycle. $\mathcal{F}$. clin. Endocr. Metab. 27, 1167.

Obst, J. M. \& Seamark, R. F. (1972) Plasma oestrogen concentrations in ewes during parturition. 7. Reprod. Fert. 28, 161, Abstr.

Sitteri, P. K. \& MACDonald, P. C. (1966) Placental estrogen biosynthesis during human pregnancy. 7. clin. Endocr. Metab. 26, 751.

SNedecor, G. W. \& Cochran, W. G. (1967) Statistical Methods, 6th edn. Iowa State University Press, Ames, Iowa.

Stabenfeldt, G. H., Drost, M. \& Franti, G. E. (1972) Peripheral plasma progesterone levels in the ewe during pregnancy and parturition. Endocrinology, 90, 144.

Thompson, F. N. \& WAGNER, W. C. (1974) Fetal-maternal corticosteroid relationships in sheep during late pregnancy. F. Reprod. Fert. 41, 49.

Thorburn, G. D. \& MAtTNer, P. E. (1971) Anastomosis of the utero-ovarian and anterior mammary vein for collection of utero-ovarian venous blood: progesterone secretion rates in cyclic ewes. F. Endocr. 50, 307.

Thorburn, G. D., Nicor, D. H., Bassetr, J. M., Shutt, D. A. \& Cox, R. I. (1972) Parturition in the goat and sheep: changes in corticosteroids, progesterone, oestrogens and prostaglandin $F$. J. Reprod. Fert., Suppl. 16, 61.

Wagner, W. C., Strohbehn, R. E. \& Harris, P. A. (1972) ACTH, corticoids and luteal function in heifers. F. Anim. Sci. 35, 789. 